Relations industrielles

Industrial Relations

\title{
Structural Reforms
}

\section{Gérard Dion}

Volume 3, numéro 3, novembre 1947

URI : https://id.erudit.org/iderudit/1023582ar

DOI : https://doi.org/10.7202/1023582ar

Aller au sommaire du numéro

Éditeur(s)

Département des relations industrielles de l’Université Laval

ISSN

0034-379X (imprimé)

1703-8138 (numérique)

Découvrir la revue

Citer ce document

Dion, G. (1947). Structural Reforms. Relations industrielles / Industrial Relations, 3(3), 48-48. https://doi.org/10.7202/1023582ar

Tous droits réservés @ C Département des relations industrielles de l’Université Laval, 1947
Ce document est protégé par la loi sur le droit d'auteur. L’utilisation des services d'Érudit (y compris la reproduction) est assujettie à sa politique d'utilisation que vous pouvez consulter en ligne.

https://apropos.erudit.org/fr/usagers/politique-dutilisation/ 


\section{STRUCTURAL REFORMS}

Those who sincerely seek to establish peace and order in this country are deeply worried by the numerous incidents which have hampered normal labour relations since the end of World war II. But however tragic may be the disputes and strikes arising between employers and employees, provoking acrid discussions, exciting passion, and entailing heavy economic consequences, they fail to prevent us from bearing in mind that at the very bottom of this chaotic situation and of this confusion in the minds of people there are other questions, more serious and more important, which require to be thoroughly studied, information that may probably lead us to discover sound durable solutions. Without neglecting to take the necessary steps to meet the various contingencies to be dealt with, we must act in accordance with the underlying principles involved; indeed it is hardly of any use to rectify certain seperate evils, if the entire social organism needs to be examined and overhauled. Sixteen years have already passed since Pope Pius XI, in pointing out his predecessors' conception of the problem, gave us the following cue: «Both morals and institutions must be reformed».

In the present issue of the Bulletin we shall tackle this highly important problem of structural reforms. This issue contains a very sound article written by a noted scholar, theologian and sociologist, the Reverend Father Paul Emile Bolté, p.s.s., professor at the Faculty of Theology of the University of Montreal, and a graduate from our Faculty. In the field of economics, reforms are required not only at the level of the undertakings but also at the level of the exercise of professions as well as of the society. These reforms are based on the problem of property and its distribution in all its forms. However, it must not be forgotten that the point at stake in the conflict between employers and employees is not merely a question of dollars and cents, but a new distribution of authority and a practical acknowledgement of the dignity of man. That is why we intend not to steer a haphazard course to the right or to the left, but to follow the principles of social doctrine of the Church, a fount of wisdom in itself, to take into account the social realities that are encountered here, and to redraft our conception of property, the undertaking, capitalism, profits, authority in labour relations, participation in ownership, co-administration, and profit-sharing.

In fact, a certain practical attitude has already been adopted. The workers, in general, except certain labour leaders, feel, in a rather indefinite but real way, the necessity for reforms in the structure of our economy. On the other hand, without always being fully aware of the long-dated incidence of certain partial reforms that they effect (and it often happens that they are utterly unacquainted with the basic principles involved), a few employers, in certain parts, have realized what is known as the guaranteed annual wage, multiple-management plans, profit-sharing and participation in the ownership of undertakings.

In spite of the grandiloquent and demagogic declarations of certain idealists, there is no such thing as a revolution taking place in the social and economic fields, if by the word revolution sudden changes are implied. History teaches that the names of things were often changed and persons replaced, and that what was really going on was merely a slow unrelentless evolutionary process. In speaking of structural reforms we are referring to a task the achievement of which demands a very long time. It is probable that present-day necessities, popular psychology and the degree of preparation of men will compel social workers to delay the carrying out of a reform, but such workers must not lose sight of the question as a whole and apply themselves entirely to details, which despite their importance will forever remain details. Therefore, they must be as perfectly conversant as possible with the principles that are to direct their action and with the facts to which such principles apply. The success of a true structural reform is at stake. 